\title{
Atrioventricular and associated intraventricular conduction disturbances in acute myocardial infarction
}

\author{
Chin Hock Lim, Charles C. S. Toh, and Lip Ping Low \\ From the Department of Clinical Medicine, University of Singapore, \\ Outram Road General Hospital, Singapore 3
}

Of 539 patients treated in the Coronary Care Unit, atrioventricular disturbance of all grades occurred in $10.8 \mathrm{per}$ cent, with an overall mortality of 34 per cent. The incidence of complete heart block was 6.6 per cent. Only 1 I of 19 patients with first degree block progressed to higher forms of atrioventricular block and only 7 developed complete heart block. Eleven of 25 patients with second degree block developed complete heart block. Of the 25 patients with inferior infarction with third degree block, II progressed through lower grades of atrioventricular block before complete heart block was established, whereas 3 of the II patients with anterior infarction behaved similarly. Sinus rhythm was re-established in 26 of the 36 patients with complete heart block and I patient had permanent heart block. There is no apparent statistically significant difference in the mortality rates of paced and unpaced patients, though the mortality might have been improved in the anterior infarction patients. Three varieties of trifascicular block were seen in 10 patients: (a) 4 patients with right bundle-branch block with left anterior hemiblock, (b) 3 patients with right bundle-branch block with left posterior hemiblock, and $(c) 3$ patients with right bundlebranch block with intermittent left posterior and left anterior hemiblock. Six of the Io patients died, reflecting the extensive myocardial damage.

With the introduction of artificial endocardial pacing, a safe and simple procedure, there has been an increased awareness and interest in atrioventricular conduction disturbances following acute myocardial infarction, and the role of pacing in this condition. Complete heart block complicates 6 to 8 per cent of all cases of acute myocardial infarction (Julian, Valentine, and Miller, 1964; Siddons and Sowton, 1967; Brown, Hunt, and Sloman, 1969; Norris, 1969) and is associated with an increased mortality rate of 40 to roo per cent (Epstein et al., 1966; Friedberg, Cohen, and Donoso, 1968; Brown et al., 1969; Kostuk and Beanlands, 1970). Transvenous endocardial pacing may help to reduce this high mortality rate, and standby pacing in anticipation of complete heart block has been advocated by some authors (Lassers and Julian, 1968; Brown et al., 1969; Norris, 1969). However, there is still controversy over the indication for the use of pacemakers and the evaluation of their beneficial effect.

Received 3I March I97I.
The aim of this study is to analyse our experiences with atrioventricular conduction disturbance in acute myocardial infarction, its natural history, the role of transvenous pacing, and the significance of trifascicular block in these patients.

\section{Material and methods}

A total of 539 patients with acute myocardial infarction was monitored in the Coronary Care Unit, Department of Clinical Medicine, General Hospital, Singapore, from April 1967 to December 1970. Facilities for artificial pacing were available only from June 1968. Before this, intravenous isoprenaline, orciprenaline, and steroids were used. First degree heart block was diagnosed if the PR interval was more than $0.22 \mathrm{sec}$, and second degree heart block diagnosed if intermittent failure of atrioventricular conduction were present. Terminal atrioventricular conduction disturbance and those occurring after direct current countershock were excluded.

A 'Device' demand type of external pacemaker was used and temporary transvenous pacing was accomplished by the insertion of a No. 5 or a No. 6 U.S.C.I. bipolar catheter electrode under 
fluoroscopy. The proximal end of the catheter was tunnelled through $4 \mathrm{~cm}$ of subcutaneous tissue to minimize retrograde infection. This has been responsible for a significant reduction in the incidence of thrombophlebitis. Intravenous isoprenaline or orciprenaline was given continuously while waiting for the insertion of the catheter electrode. Parenteral antibiotics were given daily until the catheter electrode was removed. This was done between 5 and ro days after sinus rhythm had been re-established. Nineteen patients were paced during this period, I patient with second degree block and the remaining 18 patients with complete heart block.

\section{Results}

The hospital mortality rate of 539 patients with definite acute myocardial infarction monitored in the Coronary Care Unit was 18 per cent. Some form of atrioventricular conduction defect was seen in 58 patients (10.8\%) and this group had a hospital mortality rate of 34 per cent (see Table I). Eight patients had first degree heart block which did not progress further; four of these died ( $50 \%)$. Second degree block which did not progress to complete heart block was seen in 14 patients $(2 \cdot 6 \%)$, of whom 2 died ( $14 \%$ ). Thirty-six patients had complete heart block, an incidence of 6.6 per cent; 13 of these patients died, a mortality rate of 36 per cent which was twice the hospital mortality rate of the population at risk. Of the 36 patients with complete heart block, 25 had inferior infarction, while II had anterior infarction (see Fig. 2).

Table 2 shows the mean age and fatality risk of the patients in the various grades of heart block after acute myocardial infarction. There was no statistically significant difference between the mean ages of the three groups.

Heart block was twice as common in inferior infarction as in anterior infarction and cardiogenic shock was seen more frequently in complete heart block than in first or second degree heart block (see Table 3).

Anterior infarction with heart block was associated with a slightly higher incidence of heart failure and cardiogenic shock when compared to the inferior infarction group (see Table 4).

Natural history of heart block Of the series of 58 patients, 12 presented with normal conduction on admission. Of these, 3 progressed to complete heart block suddenly without apparently passing through first or second degree block, and 4 patients progressed through first or second degree block before reaching complete heart block. Another 5
TABLE I Incidence and mortality rates of various grades of block

\begin{tabular}{lcccl}
\hline Grade & No. & Incidence $(\%)$ & Died & Mortality rate (\%) \\
\hline First degree & 8 & $1 \cdot 5$ & 4 & 50 \\
Second degree & 14 & $2 \cdot 6$ & 2 & 14 \\
Third degree & 36 & 6.6 & 13 & 36 \\
Third degree (paced) & 18 & - & 6 & 33 \\
Third degree (unpaced) & 18 & - & 7 & 38 \\
All grades & 58 & 10.8 & 19 & 34 \\
\hline
\end{tabular}

(Grade refers to the maximum degree of heart block.)

TABLE 2 Age and survival in heart block

\begin{tabular}{lcccc}
\hline Grade & No. of patients & Age $(y r)$ & & $\begin{array}{l}\text { Fatality risk } \\
\text { (per thousand) }\end{array}$ \\
\cline { 2 - 5 } & & Mean & $S D$ & \\
\hline First degree & 8 & $60 \cdot 25$ & $10 \cdot 1 \mathrm{I}$ & $4 / 8=500$ \\
Second degree & 14 & $55 \cdot 2 \mathrm{I}$ & $8 \cdot 7$ & $2 / 14=140$ \\
Third degree & 36 & $59 \cdot \mathrm{II}$ & $10 \cdot 63$ & $13 / 36=360$ \\
\hline
\end{tabular}

TABLE 3 Heart block in relation to site and severity of infarction

\begin{tabular}{|c|c|c|c|c|c|c|c|}
\hline \multirow[t]{2}{*}{ Grade } & \multicolumn{2}{|l|}{ Site } & \multicolumn{3}{|c|}{ Severity } & \multirow{2}{*}{ Paced } & \multirow{2}{*}{ Total } \\
\hline & Anterior & Inferior & $G_{I}$ & G2 & $G_{3}$ & & \\
\hline $\begin{array}{l}\text { First degree } \\
\text { Second degree } \\
\text { Third degree }\end{array}$ & $\begin{array}{r}5 \\
1 \\
\text { II }\end{array}$ & $\begin{array}{r}3 \\
13 \\
25\end{array}$ & $\begin{array}{l}3 \\
7 \\
3\end{array}$ & $\begin{array}{r}4 \\
5 \\
13\end{array}$ & $\begin{array}{r}1 \\
2 \\
20\end{array}$ & $\begin{array}{r}0 \\
1 \\
18\end{array}$ & $\begin{array}{r}8 \\
14 \\
36\end{array}$ \\
\hline Total & 17 & $4 \mathrm{I}$ & 13 & 22 & 23 & 19 & 58 \\
\hline
\end{tabular}

$G_{1}=$ uncomplicated cases; $G_{2}=$ those with left ventricular failure; $G_{3}=$ those with cardiogenic shock.

patients advanced to second degree heart block without progressing any further (see Fig. I).

(a) First degree heart block Nineteen patients presented with first degree heart block on admission. Eight patients did not progress further; 5 of these had anterior infarction. Nine patients passed through second degree block, while only 5 of these went on to reach complete heart block (all 5 had inferior infarction). Two patients went directly from first to third degree block without apparently passing through second degree block.

(b) Second degree heart block All the 8 patients who presented with second degree block on admission had inferior infarction. Only 3 progressed to complete heart block. Fourteen patients had second degree block without progressing to third degree block. 
TABLE 4 The relation of site infarction to the presence of left ventricular failure and cardiogenic shock

\begin{tabular}{|c|c|c|c|c|c|c|}
\hline \multirow[t]{2}{*}{ Grade } & \multicolumn{3}{|c|}{ Anterior infarction } & \multicolumn{3}{|c|}{ Inferior infarction } \\
\hline & $\begin{array}{l}\text { No. of } \\
\text { patients }\end{array}$ & $\begin{array}{l}\text { Left ventri- } \\
\text { cular failure }\end{array}$ & $\begin{array}{l}\text { Cardiogenic } \\
\text { shock }\end{array}$ & $\begin{array}{l}\text { No. of } \\
\text { patients }\end{array}$ & $\begin{array}{l}\text { Left ventri- } \\
\text { cular failure }\end{array}$ & $\begin{array}{l}\text { Cardiogenic } \\
\text { shock }\end{array}$ \\
\hline First degree & 5 & 2 & 0 & 3 & 3 & 0 \\
\hline Second degree & I & I & 0 & 13 & 5 & 2 \\
\hline Third degree & II & 10 & 7 & 25 & 20 & 13 \\
\hline Total & 17 & 13 & 7 & $4 \mathrm{I}$ & 28 & 15 \\
\hline
\end{tabular}

(c) Complete heart block Nineteen patients had complete heart block on admission. There was an approximately equal proportion of patients in the anterior and inferior infarction group presenting with complete heart block on admission. Of the 17 who progressed through lower grades of AV block, the average time taken by them to develop complete heart block was 29 hours. Adams-Stokes attacks were three times more common in the group who presented with complete heart block on admission (see Table 5). The average time taken for complete heart block to revert to

FIG. I The progression of atrioventricular conduction in 58 patients. The figures in squares represent the number of patients presenting on admission in that particular state of conduction. ' $A$ ' denotes patients with anterior infarction while ' $P$ ' denotes those with inferior infarction. (Fig. adapted and modified from Brown et al., 1969).

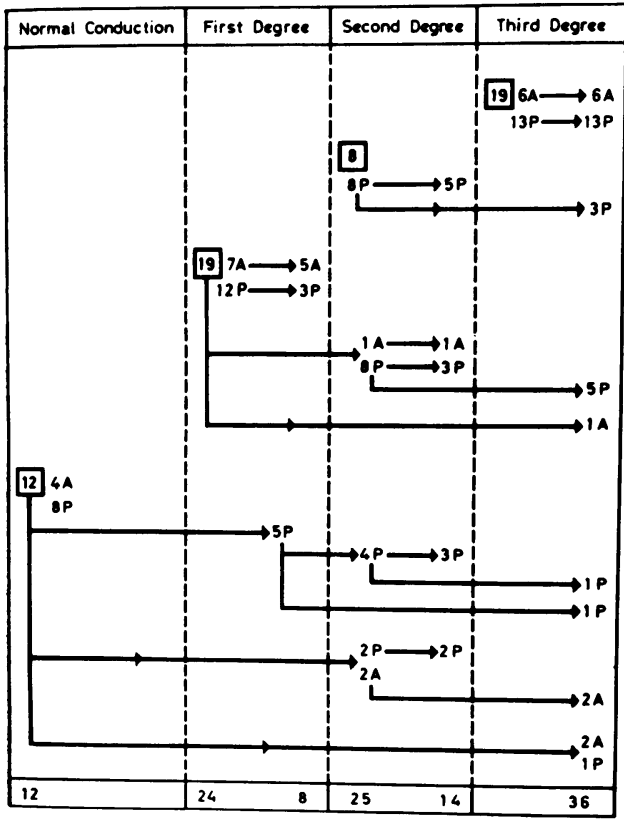

first degree block was 72 hours, while it took I22 hours for sinus rhythm to be re-established. Only in 26 of the 36 patients was normal conduction re-established, with 2 remaining in first degree and $I$ in second degree block (see Fig. 2). Six patients died in complete heart block while I had permanent complete heart block requiring permanent transvenous pacing.

The role of pacing in complete heart block There was an equal number of paced and unpaced patients ( 18 in each group). Of the 18 unpaced patients, 7 were not paced as there were no facilities for pacing at that time, while 5 died (from cardiogenic shock) before pacing could be instituted. Four patients had

FIG. 2 The re-establishment of sinus rhythm in 36 patients with complete heart block. ' $A$ ' refers to those with anterior infarction while ' $P$ ' refers to those with inferior infarction. The figure in the square refers to the 36 patients who had complete heart block.

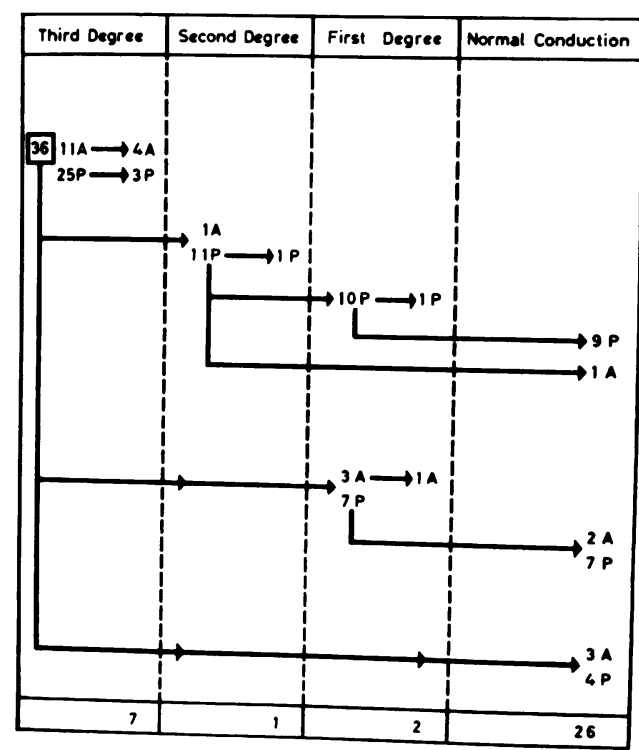


TABLE 5 Onset of complete heart block and its relation to the site of infarction

\begin{tabular}{|c|c|c|c|c|c|c|c|c|}
\hline & \multicolumn{4}{|c|}{ Anterior infarction } & \multicolumn{4}{|c|}{ Inferior infarction } \\
\hline & No. & $\begin{array}{l}\text { Adams- } \\
\text { Stokes } \\
\text { attack }\end{array}$ & Paced & Died & No. & $\begin{array}{l}\text { Adams- } \\
\text { Stokes } \\
\text { attack }\end{array}$ & Paced & Died \\
\hline $\begin{array}{l}\text { Complete heart block after admission } \\
\text { Complete heart block at admission }\end{array}$ & $\begin{array}{l}5 \\
6\end{array}$ & $\begin{array}{l}2 \\
3\end{array}$ & $\begin{array}{l}2 \\
5\end{array}$ & $\begin{array}{l}5 \\
2\end{array}$ & $\begin{array}{l}12 \\
13\end{array}$ & $\begin{array}{l}0 \\
3\end{array}$ & $\begin{array}{l}7 \\
3\end{array}$ & $\begin{array}{l}3 \\
3\end{array}$ \\
\hline Total & II & 5 & 7 & 7 & 25 & 3 & I0 & 3 \\
\hline
\end{tabular}

transient complete heart block, while 2 were not paced because they were more than 70 years of age and had a satisfactory ventricular rate with narrow QRS complexes. The mortality rate in the group with anterior infarction and complete heart block was 64 per cent which was higher than that in the inferior group $(24 \%)$. There was no statistically significant difference in the mortality rates of paced and unpaced patients (Table $I$ and 6 ), that is, 33 and 38 per cent respectively. In the inferior infarction group, pacing does not appear to improve survival. There was some selection and bias in the unpaced group as 6 patients were not paced because they had transient block or had satisfactory ventricular rates with narrow QRS complexes, thus lowering the mortality rate of this group.

There was an approximately equal number of patients less than 60 or more than 60 years in both the paced and unpaced groups. Table 7 shows that there is no significant difference between the 4 groups of patients and that there is no relation between age and mortality in paced and unpaced patients in this series.

TABLE 6 Pacing and the site of infarction

\begin{tabular}{|c|c|c|c|c|c|c|}
\hline \multirow[t]{2}{*}{ Site } & \multirow{2}{*}{$\begin{array}{l}\text { No. of } \\
\text { patients }\end{array}$} & \multirow[t]{2}{*}{ Died } & \multicolumn{2}{|c|}{ Paced } & \multicolumn{2}{|c|}{ Unpaced } \\
\hline & & & No. & Died & No. & Died \\
\hline $\begin{array}{l}\text { Anteri } \\
\text { Inferio }\end{array}$ & $\begin{array}{l}\text { II } \\
25\end{array}$ & $\begin{array}{l}7 \\
6\end{array}$ & $\begin{array}{r}8 \\
10\end{array}$ & $\begin{array}{l}4 \\
2\end{array}$ & $\begin{array}{r}3 \\
15\end{array}$ & $\begin{array}{l}3 \\
4\end{array}$ \\
\hline
\end{tabular}

TABLE 7 Relation of age and survival in paced and unpaced patients

\begin{tabular}{llllll}
\hline & \multicolumn{2}{l}{ Unpaced } & & Paced \\
\cline { 2 - 3 } \cline { 5 - 6 } \cline { 5 - 6 } & $\leqslant 60 y r$ & $>60 y r$ & & $\leqslant 0 y r$ & $>60 y r$ \\
\hline No. of patients & 8 & 10 & II & 7 \\
Died & 4 & 3 & 3 & 3 \\
Fatality & $4 / 8$ & $3 / 10$ & $3 / 11$ & $3 / 7$ \\
\hline
\end{tabular}

Onset of complete heart block and survival Twenty-three patients developed complete heart block within 24 hours, and 7 died. Thirteen patients took more than 24 hours to develop complete block; of these, 6 died. An equal proportion of patients died irrespective of the time of onset of heart block in the paced and unpaced groups (see Table 8a).

Thirty-two patients $(88 \%$ ) developed complete heart block within 48 hours and the majority of deaths (Io patients) occurred within the first 48 hours (see Table $8 b$ ).

Characteristics of the 19 patients who died in this series Nineteen patients with varying grades of $\mathrm{AV}$ block died (see Table 9). Thirteen patients died from cardiogenic shock, while 18 patients had left ventricular failure. Of the 13 with complete heart block, 6 died, despite pacing, from cardiogenic shock.

Hemiblocks Bundle-branch block was seen in 14 patients; 12 had complete heart block while there was only I patient with first degree and I with second degree heart block. Right bundle-branch block with left anterior hemiblock was seen in 4 patients. Right bundle-branch block with left posterior hemiblock was present in 3 patients. Permanent right bundle-branch block with alternating left anterior and posterior hemiblock was seen in 3 patients, while 2 patients had right bundle-branch block with a normal axis. Eight patients died in this group, a mortality rate of 57 per cent. Six patients had bundlebranch block with an abnormal axis before the onset of complete heart block, while 3 had bundle-branch block after complete heart block had reverted to sinus rhythm. In 12 patients the widened QRS complexes and abnormal axis occurred during complete heart block and they died in block.

Illustrative case history A 49-year-old Eurasian male had his first infarction in 1956 at the age of 36 . His electrocardiogram in 1956 
TABLE 8a Fatality and onset of complete heart block in paced and unpaced patients

\begin{tabular}{lllll}
\hline & \multicolumn{4}{l}{ Onset of heart block $(24 \mathrm{hr})$} \\
\cline { 2 - 5 } & Paced & Unpaced & Paced & Unpaced \\
\hline No. of patients & 8 & 15 & I0 & 3 \\
Died & I & 6 & 5 & I \\
Fatality & I/8 & $6 / 15$ & $5 / 10$ & I/3 \\
\hline
\end{tabular}

TABLE 8b Mortality in relation to onset of complete heart block

\begin{tabular}{lrlll}
\hline $\begin{array}{l}\text { Onset of heart } \\
\text { block }\end{array}$ & $\begin{array}{c}\leqslant 24 \\
h r\end{array}$ & $\begin{array}{l}25-48 \\
h r\end{array}$ & $\begin{array}{l}49-72 \\
h r\end{array}$ & $\begin{array}{l}>72 \\
h r\end{array}$ \\
\hline $\begin{array}{l}\text { No. of patients } \\
\text { No. died }\end{array}$ & 30 & 2 & $\circ$ & 4 \\
\hline
\end{tabular}

showed anteroseptal infarction with right bundle-branch block and a QRS axis of $+120^{\circ}$ (Fig. 3). Between 1956 and 1962 , he was readmitted three times for episodes of paroxysmal atrial tachycardia. In 1962, the 12-lead electrocardiogram showed right bundle-branch block with a QRS axis of $-60^{\circ}$, showing that he had permanent right bundle-branch block with intermittent left posterior and anterior hemiblock (Fig. 4). In 1969, he was readmitted for chest pain and developed frequent Adams-Stokes attacks; the electrocardiogram revealed complete heart block with left axis deviation $\left(-60^{\circ}\right)$. Temporary transvenous pacing was carried
TABLE 9 Characteristics of 19 patients who died in this series

\begin{tabular}{lccccc}
\hline Grade of block & $\begin{array}{l}\text { No. of } \\
\text { patients }\end{array}$ & Paced & $\begin{array}{l}\text { Left } \\
\text { ventricular } \\
\text { failure }\end{array}$ & $\begin{array}{l}\text { Cardiogenic } \\
\text { shock }\end{array}$ & $\begin{array}{l}\text { Died in } \\
\text { block }\end{array}$ \\
\hline First degree & 4 & 0 & 3 & I & 0 \\
Second degree & 2 & 0 & 2 & 0 & 0 \\
Third degree & 13 & 6 & 13 & 12 & 7 \\
\hline
\end{tabular}

out, but as he did not show any evidence of reversion to sinus rhythm after three weeks, a permanent pacemaker generator was implanted. Since then he has been free of symptoms.

This case illustrates one of the varieties of trifascicular block (Rosenbaum et al., 1969) where there is permanent right bundlebranch block and intermittent block in the left anterior and posterior fascicles, ultimately progressing to complete heart block due to permanent block in both the left fascicles.

\section{Discussion}

Atrioventricular conduction disturbance is a serious and not uncommon complication following acute myocardial infarction, and meaningful figures of its incidence are obtained only in Coronary Care Units where continuous monitoring is carried out. The incidence of complete heart block (10.8\%) after acute myocardial infarction in this series is comparable to the published figures of other authors (Courter, Moffat, and Fowler, 1963; Brown et al., 1969; Kostuk and

TABLE IO I4 patients with bundle-branch block and their axis

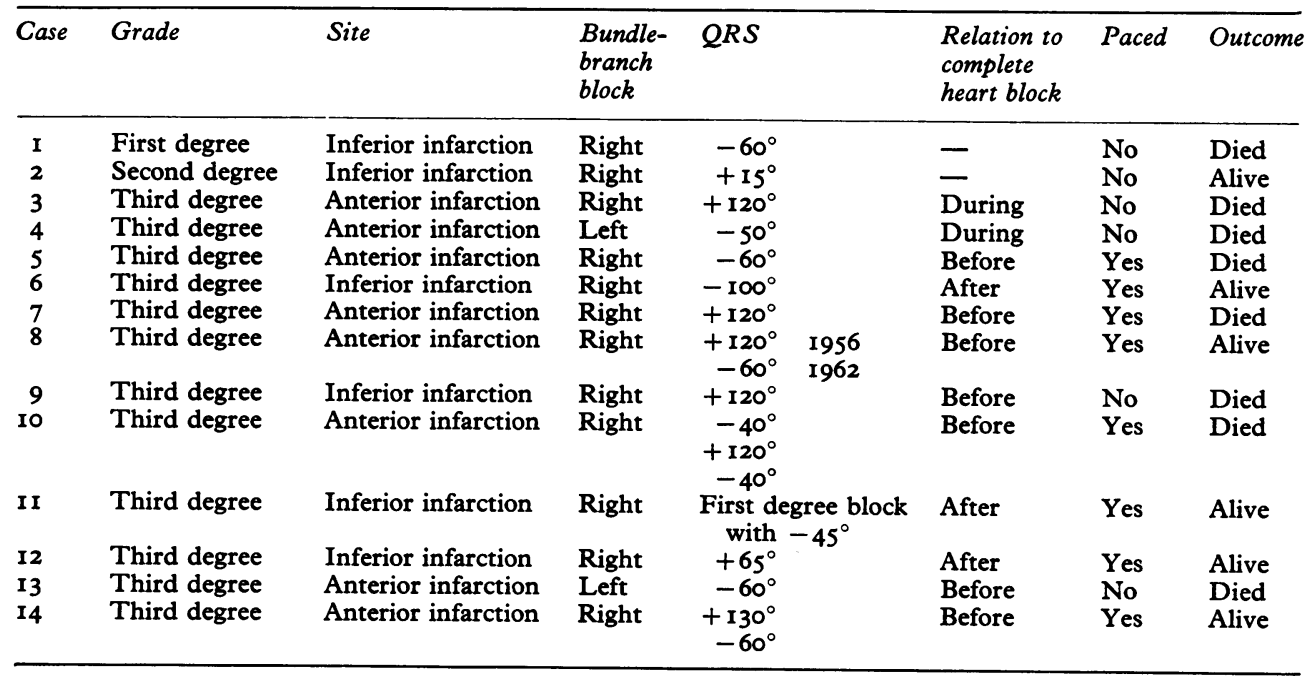


Beanlands, 1970). First and second degree block not progressing to higher grades of block was seen in 1.5 and 2.6 per cent of patients, respectively.

Among patients with infarction developing complete heart block, 69 per cent had inferior infarction. In the series of Julian, Lassers, and Godman (I969), it was 60 to 70 per cent, showing that complete heart block was twice as common' in inferior compared with anterior infarction. The reason for this increased frequency in inferior infarction is because the right coronary artery in 90 per cent of hearts supplies the atrioventricular junctional tissue (James, 1968). Its function is interfered with because of oedema and ischaemia of contiguous myocardial tissue rather than by direct involvement. Necropsy studies by Harris et al. (1969) confirmed this.

Complete heart block developed within 24 hours of onset of pain in 85 per cent of patients, and the average time taken to develop complete heart block, while being observed in the Coronary Care Unit, was 29 hours. This was the same experience as other authors who noticed the onset of heart block usually within the first day of infarction and rarely occurring after the fourth day (Adgey et al., I968; Julian et al., 1969).

The development of complete heart block in inferior infarction has been described as more benign and predictable compared to anterior infarction, as it rarely appears suddenly and is usually preceded by lower grades of AV block (Brown et al., I969; Lown and Kosowsky, 1970; Norris and Croxson, 1970). This characteristic was also seen in this series, as II of the II patients with inferior infarction who developed third degree block in the Coronary Care Unit progressed through first or second degree heart block (Fig. I), whereas only 3 out of the II with anterior infarction appeared to have progressed through first or second degree block. In the majority of cases, heart block is often transient, returning to sinus rhythm within a few days. The average time taken for complete heart block to revert to first degree block was 72 hours, while it took 122 hours for normal conduction to be restored. Only one patient had permanent complete heart block and required permanent pacing. In 29 patients normal conduction was re-established, the inferior infarction group showing a progression through second and first degree sequentially ( 9 out of 20 patients), while 7 out of 20 were observed to progress directly to first degree without apparently passing through second degree block. This can be attributed to the infrequent periods when the pacemaker is turned off to check the

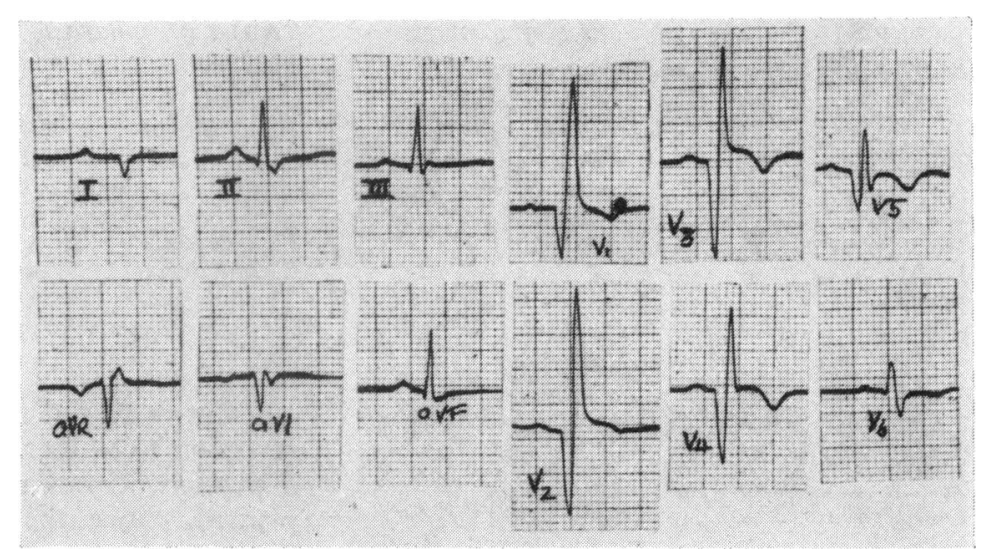

FIG. 3 A 36-year-old man. The I 2-lead electrocardiogram in November 1956 shows anterior infarction with right bundle-branch block and left posterior hemiblock ( $Q R S=$ $\left.+120^{\circ}\right)$.

intrinsic rhythm, and it is during the period of pacing that the reversion through second degree block was possibly undetected.

The mortality rate for unpaced patients with complete heart block was 38 per cent, while it was 33 per cent for the paced group. This overall figure of 33 per cent is comparable with the published results of other authors (Epstein et al., 1966; Beregovich et al., 1969).

Apparently no significant difference in mortality rates exists between paced and unpaced patients in this series, though pacing in those

FIG. 4 I2-Lead electrocardiogram in April 1962 shows anterior infarct with right bundlebranch block and left anterior hemiblock $\left(Q R S\right.$ axis $\left.=-60^{\circ}\right)$.

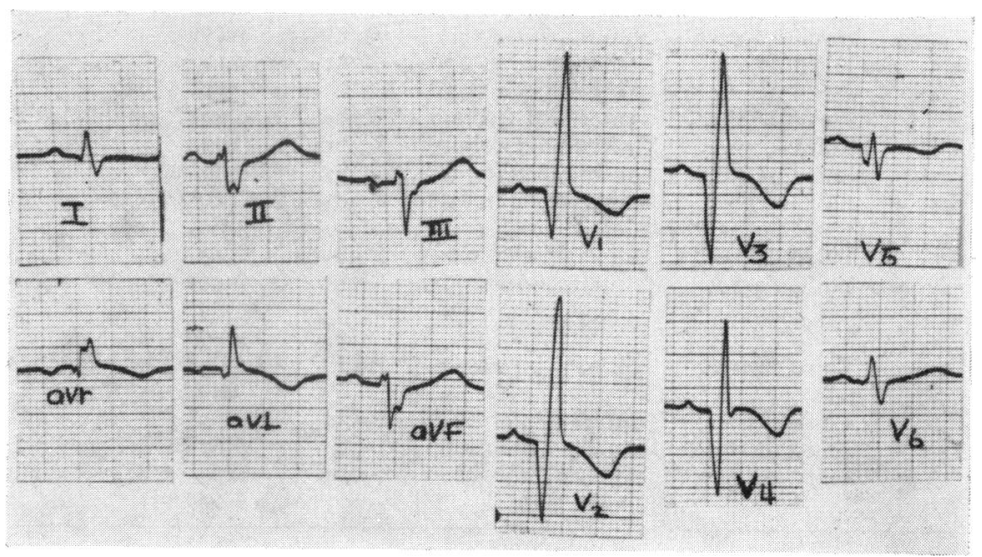


with anterior infarction appeared to have lowered mortality in this group; the fatality was 4 out of 8 in the paced group, and 3 out of 3 in the unpaced group. The figures are, however, too small for statistical evaluation. Pacing did not alter the mortality rates signifi-

- cantly in the inferior infarction group ( 2 out of 10 in paced and 4 out of 15 in unpaced group), whose overall mortality rate of 24 per cent was not very different from the mortality rate of the overall series which was 18 per cent, showing that the patients with inferior infarction complicated by complete , heart block did not fare very differently from those without this complication. Julian et al. (1969), Friedberg et al. (1968), and Lassers and Julian (1968) noted that in patients with complete heart block accompanying inferior infarction not complicated by shock, heart failure, or wide QRS complexes or syncope, the survival was not much worse than those

without heart block and when one or more of the above complications sets in, the prognosis was said to be poor despite the early institution of pacing. On the other hand, pacing in complete heart block complicating anterior infarction is claimed to be of limited value because of the extent of myocardial damage. $\therefore$ However, pacing still has an important role in preventing deaths which may result from bradycardia or asystole which may be impervious to drug therapy. It allows one greater freedom in the use of digitalis and other antiarrhythmic drugs, which in the absence of pacing may lead to undesirable arrhythmias.

Standby pacing or the insertion of a pacemaker electrode even before the onset of complete heart block has been advocated in first degree, second degree, or bundle-branch block. Sloman (1969) advises standby pacing in first degree heart block complicating anterior infarction. However, 8 of the 19 patients with first degree block did not progress further and only I of the 7 patients with first - degree block complicating anterior infarction progressed to complete heart block. Less than half of the patients with second degree block (I I out of 25) progressed to complete heart block.

Rosenbaum et al. (1969) and Rosenbaum (1970) have described the trifascicular nature of the conducting system of the heart, and that complete heart block can occur distal to the AV node when all the three fascicles have been involved by disease. Three varieties of trifascicular block were seen in this series. (a) Right bundle-branch block with left anterior hemiblock (4 patients); (b) right bundlebranch block with left posterior hemiblock ( 3 patients); and (c) right bundle-branch block with intermittent left anterior and left posterior hemiblock (3 patients).

One patient had right bundle-branch block with a normal axis of $+65^{\circ}$ and the right bundle-branch block was temporary. Left bundle-branch block with an axis of $-60^{\circ}$ was seen in I patient before the onset of third degree block. Six of the Io patients with trifascicular block died, reflecting the extensive myocardial damage present, and pacing did not alter the mortality as those who succumbed died from cardiogenic shock. Five of the ro patients with trifascicular block presented with complete heart block suddenly. Complete heart block was more frequent in patients with right bundle-branch block (I0) compared to those with left bundlebranch block (2). Norris and Croxson (1970) have advocated the insertion of pacemaker electrodes in patients developing right bundlebranch block.

Pacing still remains an important form of therapy in the management of patients with complete heart block, for during the period of block the slow heart rate and myocardial damage lead to a reduced cardiac output (Sowton, I964). The diseased myocardium is incapable of increasing its stroke volume, so that changes in cardiac output are completely dependent on heart rate (Sowton, 1964). The presence of cardiogenic shock and heart failure are poor prognostic features (Lassers and Julian, 1968), and in this series, of the 13 patients who died, all had left ventricular failure and 12 had cardiogenic shock. It is the policy of the Unit to pace all patients with complete heart block complicating myocardial infarction, whose ventricular rate falls below critical values leading to haemodynamic disturbances, who develop Adams-Stokes attacks, and who show wide QRS complexes. Those patients with anterior infarction demand more urgent attention than those with inferior infarction.

We wish to acknowledge with thanks the help given by the staff of the Radiology Department. We are indebted to the Coronary Care Unit Nursing Staff for their intelligent and continued devotion to the care of the sick.

\section{References}

Adgey, A. A. J., Geddes, J. S., Mulholland, H. C., Keegan, D. A. J., and Pantridge, J. F. (I968). Incidence, significance, and management of early bradyarrhythmia complicating acute myocardial infarction. Lancet, 2, 1097.

Beregovich, J., Fenig, S., Lasser, J., and Allen, D. (1969). Management of acute myocardial infarction complicated by advanced atrioventricular block. Role of artificial pacing. American fournal of Cardiology, 23, 54 . 
Brown, R. W., Hunt, D., and Sloman, J. G. (1969). The natural history of atrioventricular conduction defects in acute myocardial infarction. American Heart fournal, 78, 460 .

Courter, S. R., Moffat, J., and Fowler, N. O. (1963). Advanced atrioventricular block in acute myocardial infarction. Circulation, 27, 1034

Epstein, E. J., Coulshed, N., McKendrick, C. S., Clarke, J., and Keans, W. F. (1966). Artificial pacing by electrode catheter for heart block or asystole complicating acute myocardial infarction. British Heart fournal, 28, 546.

Friedberg, C. K., Cohen, H., and Donoso, E. (1968). Advanced heart block as a complication of acute myocardial infarction. Role of pacemaker therapy. Progress in Cardiovascular Diseases, 10, 466.

Harris, A., Davies, M., Redwood, D., Leatham, A., and Siddons, H. (1969). Aetiology of chronic heart block; a clinicopathological correlation in 65 cases. British Heart fournal, 31, 206.

James, T. N. (1968). The coronary circulation and conduction system in acute myocardial infarction. Progress in Cardiovascular Diseases, 10, 410.

Julian, D. G., Lassers, B. W., and Godman, M. J. (1969). Pacing for heart block in acute myocardial infarction. Annals of the New York Academy of Sciences, 167, 91 I.

Julian, D. G., Valentine, P. A., and Miller, G. G. (I964). Disturbances of rate, rhythm and conduction in acute myocardial infarction. American fournal of Medicine, 37, 915.

Kostuk, W. J., and Beanlands, D. S. (1970). Complete heart block associated with acute myocardial infarction. American fournal of Cardiology, 26, 380.

Lassers, B. W., and Julian, D. G. (1968). Artificial pacing in management of complete heart complicating acute myocardial infarction. British Medical fournal, 2, 142.

Lown, B., and Kosowsky, B. D. (1970). Artificial cardiac pacemakers. New England fournal of Medicine, 283, 97 I.

Norris, R. M. (1969). Heart block in posterior and anterior myocardial infarction. British Heart fournal, 31, 352.

Norris, R. M., and Croxson, M. S. (1970). Bundle branch block in acute myocardial infarction. American Heart fournal, 79, 728.

Rosenbaum, M. B. (1970). The hemiblocks: diagnostic criteria and clinical significance. Modern Concepts of Cardiovascular Disease, 39, 141.

Rosenbaum, M. B., Elizari, M. V., Lazzari, J. O., Nau, G. J., Levi, R. J., and Halpern, M. S. (1969). Intraventricular trifascicular blocks. Review of the literature and classification. American Heart fournal, 78, 450 .

Siddons, H., and Sowton, E. (1967). Cardiac Pacemakers. Charles C. Thomas, Springfield, Illinois.

Sloman, G. (1969). Changing concepts in the care of patients with acute myocardial infarction. Medical Fournal of Australia, I, I 57.

Sowton, E. (1964). Haemodynamic studies in patients with artificial pacemakers. British Heart fournal, 26, 737 .

Requests for reprints to Professor Charles Toh, Department of Clinical Medicine, University of Singapore, Outram Road General Hospital, Sepoy Lines, Singapore 3. 